\title{
Tax governance: how the EU supports third countries
}

\author{
Andrea RAIMONDI \\ Unidroit, Rome, Italy \\ raimondi.andrea@hotmail.com \\ Daniel BUDA \\ Babes-Bolyai University, Cluj-Napoca, Romania \\ daniel.buda@fspac.ro \\ Sorin Cristian NIŢ $\breve{A}$ \\ Bucharest University of Economic Studies, Bucharest, România \\ cristians.nita@fabiz.ase.ro \\ Maria PISTALU \\ Bucharest University of Economic Studies, Bucharest, România \\ maria.pistalu@eam.ase.ro
}

\begin{abstract}
This paper aims to provide an analysis of the legislative framework that regulates the inclusion of clauses on good governance in tax matters, in the agreements concluded between the European Union, with its Member States, and third countries. We provide a representation of the regulatory pathway from a set of standards on tax good governance according to the principles of transparency, exchange of information and fair tax competition towards a common EU external strategy for effective taxation.

Agreements that the European Union has either in place or negotiating with countries and regions around the world are an excellent tool in fighting unfair trade practices and promoting international standards on good governance in the tax area, and set the basis for a fair competition in the economy of developing countries: a strong tax administration and institutions responsible for fighting illicit financial flows in developing countries can contribute to erase poverty and inequalities while promoting good governance and state-building.
\end{abstract}

Keywords: tax governance, European Union, third countries.

\section{Introduction}

According to the Organisation for Economic Co-operation and Development (OECD), at the end of 2008 the world's tax havens attracted between five and seven trillion dollars (USD) in assets, "although the degree of secrecy surrounding these accounts makes it difficult to determine exactly just how much is located in these individual jurisdictions." (European Commission, 2009). A solution was identified through managing the effects by means of agreements with third countries covering common standards and cooperation on tax matters. Promoting fairness and transparency in tax systems ensures stability of financial markets and strengthens the cooperation between the European Union and third countries. Hence the need to promote good governance through international rules on transparency in financial matters, and administrative cooperation in the tax area, including trade agreements (European Commission, 2009).

Good governance in tax matters is an important pre-condition for preserving the integrity of the financial market and sets out actions against non-cooperative countries that refuse to apply provisions on transparency, exchange of information and fair tax competition. Though sanctions 
were deployed to protect the EU financial system, there are still certain third countries that are not cooperating and instead continue to make use of practices leading to the proliferation of tax havens; for instance, the use of special regimes in order to attract businesses. (Herkenrath, 2014; Hoinaru, 2017; Hoinaru et al. 2020)

The European Union has adopted measures to clamp down on practices aimed at tax evasion and tax fraud, while at the same time it also strengthened the fight against corruption, money laundering, and financing of terrorism. There is a growing global consensus on the need to continue a co-ordinated response to this issue, consisting of complementary initiatives in the areas of financial regulation and taxation, and efforts have been made within the framework of cooperation with third countries on the implementation of international standards (News \& Speeches ICC, 2017).

The EU should seek a coordinated approach among its Member States as to promote the inclusion of international standards on tax cooperation in bilateral tax treaties between its Member States and third countries. The EU and its partners should focus their economic relations on harmonised tax governance provisions and work together according to the principles of mutual assistance in tax recovery. (Pirvu, 2012)

\section{The legislative pathway from good governance criteria in the tax area}

Principles on good governance in the tax area were defined in May 2008, when the Economic and Financial Affairs Council (ECOFIN) adopted EU standard provisions on transparency, exchange of information and fair tax competition. The ECOFIN recognised the need to promote good governance in the tax area on as broad a geographical basis as possible and called to include provisions in the agreements concluded by the European Union with third countries or thirdcountry groupings. The objective was to reach a common ground on principles of tax cooperation and transparency with as many third countries as possible.

In little more than a decade, we have assisted to an evolution of the above defining criteria driven by the need to adapt the agreed standards to a constantly evolving financial market. In the European Union, although Member States are free to design their tax systems, having de facto the power to tax in their hands, they have agreed on several measures aimed to promote good governance in the tax area, harmonising national legislations towards common standards in fighting against tax evasion and avoidance. These measures include provisions on administrative cooperation, harmful tax competition, state aids, transparency and exchange of information. The latter was established in 1977 through the Directive on Mutual Assistance which was replaced in 2011 by the Directive on administrative cooperation in the field of taxation, and recalled in the Directive on Savings Taxation, repealed in November 2015. This exchange of information between Member States, and Member States and third countries' tax administrations, is crucial for "enhancing the correct assessment of taxes in cross-border situations and of fighting fraud." (Council Directive 2011/16/EU). The successive adoption of an automatic Exchange of Information mechanism was critical for enhancing global transparency and cooperation in the fight against tax avoidance and evasion (Elliffe, 2019). We consider it like a component that goes hand in hand with administrative cooperation through which Member States can contribute, for instance, to counter VAT fraud across the EU. We believe it is vital that third countries exchange their information on taxpayers at the request of Member States and that trade agreements, concluded between the EU with a third country, are a tool for all parties involved to agree on evolving international standards on administrative cooperation and exchange of information. Trade 
agreements should therefore serve as an incentive for developing countries to raise the needed capacity to send and process information (Hoinaru \& Nastase, 2019; Damen, 2020).

The Code of Conduct for business taxation, set up by the ECOFIN in 1998, has a relevant role in examining key elements to be contained in these agreements as well as establishing an EU list of non-cooperative jurisdictions. This represents a defensive measure on the EU level against tax havens, as included in the Council Conclusions on an external taxation strategy and measures against tax treaty abuse of 25 May 2016.

In that circumstance, the Council fully supported the need to intensify actions to tackle tax fraud, tax evasion and aggressive tax planning, implementing updated provisions - in line with the evolution of international standards - on countering cross-border tax fraud, evasion, corruption, money laundering and terrorism financing, to be included in ongoing and future negotiations with third countries. As a result, in May 2018, the Council adopted its conclusions on the EU standard provision on good governance in tax matters for agreements with third countries which defined the core elements of global standards on transparency, exchange of information, fair taxation and anti-Base Erosion and Profit Shifting, proposing to include the following revised text in relevant agreements:

"The Parties recognise and commit themselves to implement the principles of good governance in the tax area, including the global standards on transparency and exchange of information, fair taxation, and the minimum standards against Base Erosion and Profit Shifting (BEPS)." (European Council, 2018)

We consider the above as satisfactory conditions; nevertheless, continued support in terms of finance, technical expertise and time, is needed for several third countries, notably low-income countries (LICs), towards a full implementation of reforms aimed at closing legal gaps in the area of fight against tax havens and evasion.

The proposal continues, "The Parties will promote good governance in tax matters, improve international cooperation in the tax area and facilitate the collection of tax revenues." The new revised text aligns EU standards in relevant agreements and addresses progress in the international tax agenda.

The inclusion of anti-BEPS provisions was the result of the adoption, by the European Commission, of its Anti-Tax Avoidance Package based on the following three pillars: (i) ensuring effective taxation in the EU; (ii) increasing tax transparency; (iii) securing a level playing field. The purpose of this paper is to provide a general representation of the measures which regulate tax governance criteria in bilateral and EU agreements with third countries; for this reason, we will not deepen the aspects included in the Anti-Tax Avoidance Directive, but rather consider the new provisions on the implementation of measures against tax treaty abuse and an external strategy for effective taxation promoted through the Directive (European Council, 2018).

\section{Revised criteria for a strategy for developing countries}

The European market is made of companies that generate their profits in Member States, benefit from the single market and, by consequence, should also pay taxes on their profits in the country where their activities take place. We are living in a globalised market where corporate structures have become complex as corporate decisions have adapted to the markets' evolution towards digital. While this made the shifting profits easier, determining which country should tax the income of a multinational company became more difficult over the last years. Taxation must go hand in hand with market evolution in order to promote sustainable revenues and support a better market environment for taxpayers and businesses. In this sense, bilateral tax treaties between 
Member States, as well as between Member States and third countries on transfer pricing and avoiding double taxation, can play a crucial role in preventing behaviours of companies artificially shifting profits to lower tax jurisdictions. For their parts, Member States should refrain from setting tax measures with the mere goal to attract multinational companies, and consequently move their legal headquarter for tax breaks. The Council, in its report on Code of Conduct (Business Taxation), in 1999 already included measures providing "an effective level of taxation which is significantly lower than the general level of taxation in the country concerned," among the criteria for identifying potentially harmful measures. An excessive use of this practice has also increased third countries' fiscal attractiveness towards European companies; a more harmonised European tax policy could contribute to implement an EU external relation policy integrated with provisions on tax governance able to strengthen the European response to external threats (Recommendation 2012, 2016).

Through its Communication on an external strategy for effective taxation, which belongs to the Directive's pillar on securing a level playing field, the European Commission re-examined good governance criteria, therefore adapting them to new financial risks, enhancing tax good governance cooperation through agreements with third countries. Recalling the core minimum standards as defined in 2008, the Commission introduced OECD/G20 global standards on Automatic Exchange of Information and additional standards based on the G20/OECD BEPS, as well as ones on Combating Money Laundering and on the Financing of Terrorism and Proliferation.

The new criteria seek to improve the use of international EU agreements with the aim to promote tax governance and support developing countries on corporate taxation. Jurisdictions joining the OECD/G20 Inclusive Framework on BEPS commit to implement international standards on countering harmful tax practices, tax treaty abuse, transfer pricing documentation and Country-by-Country $(\mathrm{CbC})$ reporting, improving dispute resolution mechanisms. Nevertheless, being the BEPS action plan not legally binding, developing countries can adopt standards based on the G20/OECD BEPS through the Multilateral Convention on Mutual Administrative Assistance in Tax Matters, and the Multilateral Competent Authority Agreement (MCAA), which are, on the other hand, both binding instruments for third countries (OECD, 2021).

Besides the introduction of the above criteria, the Communication's strategy included measures aimed at assisting developing countries in meeting tax good governance standards according to the Collect More, Spend Better approach, and developing an EU process for assessing and listing third countries on their compliance with international standards.

Monitoring tax systems is part of the exercise of democratic control, as tax havens run counter to the principles of solidarity and justice. Measures taken at the level of international organisations and the European Union have created encouraging results with visible effects, but which must be followed by increasingly decisive actions to combat all forms of tax havens and tax evasion. Combating these inequalities is a key element in rebuilding both global and European economy after the Covid-19 pandemic. Implementing the principles of tax good governance requires a joint work which involves both developing and developed countries. In this way, less developed countries will have a lower percentage of the population living in poverty (Recommendation 2012a, 2012b, 2016).

It is imperative that the European Union maintains its standards of good fiscal governance in relation to third countries, so that no compromises are made that could set dangerous precedents for Member States. The European Union must be an example of good governance in the field of taxation and promote compliance with improved standards at the level of the OECD. In the absence of harmonised legislation and common rules, there will still be legal gaps that will make it more 
difficult to fight against tax havens and evasion. "Trade agreements should support the promotion of international standards of transparency and good governance" (European Commission, 2015). At the same time, the European Union must not neglect its commitment to respect the principles of mutual responsibility, as set out in the Paris Declaration on Aid Effectiveness. "Thus, better fiscal governance in developing countries will increase the willingness of EU taxpayers to support development aid" (

In light of all these considerations, there is a need for clear and internationally consistent criteria for good fiscal governance that are applied in a uniform manner (Păunescu and Mátyus, 2020; Nicolescu and Drăgan, 2020). The European Union, as a major international economic and political player, has an important role to play in further supporting the BEPS project, both within the single market and internationally (Viray, 2017; Remeur, 2019).

The new criteria adapt to third countries' economic reforms on anti-money laundering and counter terrorism financing, as well as to the rate of cooperation on tax matters with the European Union. Considering the diverse economic and political institutions of the EU partners, granting flexibility over tax good governance provisions may facilitate negotiations with third countries. Analysing the most recent agreements concluded by the EU with third countries, we found out that the Framework Agreement with South Korea and Partnership Agreements with Japan and Canada include tax governance provisions based on the 2008 criteria on transparency, exchange of information and fair tax competition, along with provisions on avoidance of harmful tax practices. On the other hand, the Strategic Agenda for Cooperation between the EU and China provides the sole requirement to adopt Global Standard on automatic exchange of information, while the Free Trade Agreements with Colombia and Peru include provisions on transparency, exchange of information and fight against money laundering and terrorism financing.

Although China and South Korea are among the developing countries of the UN World Economic Situation Prospect of 2019, we consider these countries as advanced economies; South Korea became the 12th largest economy in the world in terms of GDP, according to the 2019 ranking of the World Bank, while China, the second largest economy in the world, remains the largest developing country as shown by the same report. For Colombia and Peru, which have the highest percentage of citizens who consider government corruption to be a big problem according to the 2019 Global Corruption Barometer of Transparency International, agreements concluded with the EU remain strategic in carrying out the necessary reforms at institutional level to fight against corruption and organised crimes (Citizens' Views, 2019).

Despite the growing investments of third countries such as China, in the economies of developing countries in recent years, domestic resources still represent the most stable source of income. Nevertheless, due to outgoing capital flows, such as illicit financial flows and cross-border capital movements financing illegal activities, developing countries seem to lose their domestic resources. Besides this increased capital mobility, it is estimated that they lose towards tax havens more than what they get in aid, prejudicing conditions for taxation and promotion of private and public investment in-house.

According to the European Parliament resolution of 8 July 2015 on tax avoidance and tax evasion as challenges for governance, social protection and development in developing countries, the tax-to-GDP ratio, which represents the measure of tax revenue of a nation related to the size of its economy, is still too low in developing countries (Members' Research Service, 2013; Caplescu et al., 2020). It varies between $10 \%$ and $20 \%$ in LICs and, in many such countries, does not reach the threshold of $15 \%$ for generating sufficient domestic resources which can be invested in economic growth. In EU countries, it is between $41 \%$ and $42 \%$ according to a 2019 Eurostat report 
on Taxation. The Resolution also shows that "tax resources remain low as a proportion of GDP in most developing countries, making them particularly vulnerable to the tax evasion and avoidance activities of individual taxpayers and companies"; it is therefore essential to ensure a fair and equal taxation recovery.

Through its pivotal position in the continental and global context, the European Union ought to be playing a leading role in pushing up the efforts to combat tax heavens, fraud and evasion at international level. The EU should also cooperate with developing countries in order to combat those transnational companies that use to engage in tax avoidance practices, while at the same time seek ways to help them withstand pressures to engage in tax competition. We believe that adhering to international standards on tax good governance through trade and partnership agreements can strongly contribute to adopt necessary reforms to fight against money laundering, terrorism financing, tax evasion and avoidance, creating a fair and equal system that generates incomes and promotes legality. Also, developing countries will be encouraged to establish new public institutions, such as a national and independent anti-fraud office, tasked with combating financial and fiscal fraud while protecting the financial interests. Promoting good public policies with the aim to increase developing countries' domestic revenues, as to mobilise much-needed resources for sustainable development, will support actions to eradicate poverty, fight inequalities - ensuring a fair tax recovery - and combat corruption (Kaili et.al, 2019; Staff Working Document, 2015).

\section{Conclusions}

Good governance is a global challenge that requires global solutions. The actions implemented by the European Union over the years have certainly brought benefits to the internal market, enabling a fairer and more effective corporate taxation. The European Union has recently implemented measures aimed at the harmonisation of the tax systems across national legislations with the purpose to reduce the risk of harmful tax measures which attract companies from Member States with a higher taxation. Most important is to develop a common awareness, since threats on the Single Market lie outside the Union, not inside. For that reason, the EU needs to speak with a common voice. (Kaili et al. 2019)

Competitive conditions for European companies are vital in trade agreements concluded with developing countries, where the emerging of new markets reveals export opportunities. On the other hand, the risk of developing countries attracting European companies to produce there it is still high, even more so for multinationals. Besides that, the cost of labour in those countries is quite far from the European standards. This represents a major point of discussion in national policy debates. It is therefore necessary to introduce social security provisions in these countries, which do adequately protect workers and bring them closer to EU standards. Nevertheless, the development of effective welfare policies, as we have seen, cannot be implemented whilst the mobility of capitals in developing countries remains so high. Trade agreements concluded by the European Union represent, for those countries, a big incentive when they include standards on good governance in tax matters. Developing countries adhering to standards on transparency, exchange of information and fair tax competition need to adopt measures aimed at maintaining private and public investments, while fighting against the mobilisation of illicit financial flows (Herkenrath, 2014; Hurley, Gülasan, 2015; Hoinaru 2017).

We can conclude that only through the sharing of adequate standards on money laundering, automatic exchange of information and minimum standards against BEPS, third countries, mostly 
developing countries, will hold enough domestic resources to finance welfare measures, and combat the inequality between their citizens.

Trade and partnership agreements concluded with the EU have two main advantages: (i) favour the circulation of goods and services in the Single Market and (ii) subtract money from the organised crime, which would otherwise finance illicit traffics and terrorism.

\section{References}

Caplescu, RD., Panaite, AM., Pele, DT, Strat, VA. (2020), "Will they repay their debt? Identification of borrowers likely to be charged off", Management \& Marketing. Challenges for the Knowledge Society, 15(3), 393-409, DOI: 10.2478/mmcks-20200023.

Citizens' Views and Experiences of Corruption, Global Corruption Barometer, Latin America \& the Caribbean 2019, Transparency International.

Communication (2009) from the Commission to the Council, the European Parliament and the European Economic and Social Committee: Promoting Good Governance in Tax Matters.

Communication (2010) from the Commission to the European Parliament, the Council and the European Economic and Social Committee: Tax and Development Cooperating with Developing Countries on Promoting Good Governance in Tax Matters.

Communication (2016) from the Commission to the European Parliament and the Council: AntiTax Avoidance Package: Next steps towards delivering effective taxation and greater tax transparency in the EU.

Communication (2016) from the Commission to the European Parliament and the Council on an External Strategy for Effective Taxation.

Conclusions (2016) from the Council on an external taxation strategy and measures against tax treaty abuse.

Council Directive (2011). Administrative cooperation in the field of taxation (2011/16/EU).

Damen, M. (2020). The European Union and its trade partners, Fact Sheets on the European Union, European Parliament.

Decision (2019) from the Commission on the renewal of the Commission Expert Group 'Platform for Tax Good Governance, Aggressive Tax Planning and Double Taxation'.

Elliffe, C. (2019). The Meaning of the Principal Purpose Test: One Ring to Bind Them All?. World Tax Journal, 11(1). Available at SSRN: https://ssrn.com/abstract=3346660.

European Commission (2009). Promoting Good Governance in Tax Matters. (COM/2009/0201).

European Commission (2010). Cooperating with Developing Countries on Promoting Good Governance in Tax Matters. (COM 2010) 163 Final.

European Commission (2015). Trade for all. Towards a more responsible and investment policy.

European Council (2018). Tax Fraud: Standard provision agreed for agreements with third countries, Press release 25 May 2018.

Herkenrath, M. (2014). Illicit financial flows and their developmental impacts: An overview. International Development Policy| Revue internationale de politique de développement, (5.3), https://doi.org/10.4000/poldev.1863.

Hurley, G., Gülasan, N. (2015). Financing development through better domestic resource mobilization, Blog of United Nations Development Programme.

Hoinaru, R. (2017). Follow the money. The impact of the illicit financial flows home and abroad. A common European-African perspective, Romanian Journal of Economics, 44(1 (53)), 87-94. 
Hoinaru, R., \& Năstase, M. (2019). A balanced approach: Brexit from political and business perspectives. In Proceedings of the International Conference on Business Excellence, 13(1), 804-816.

Hoinaru, R., Buda, D., Borlea, S. N., Văidean, V. L., \& Achim, M. V. (2020). The impact of corruption and shadow economy on the economic and sustainable development. Do they "sand the wheels" or "grease the wheels"?, Sustainability, 12(2), 481.

Kaili, E., Psarrakis, D., van Hoinaru, R., (2019). New models of Financing and Financial Reporting for European SMEs, Palgrave Macmillan, Cham.

Members' Research Service (2013). Parliament's Enhanced Role in International Agreements, European Parliamentary Research Service Blog.

Mosquera, I. (2019). Tax Governance and the PPT, Inter-American Center of Tax Administrations Mosquera Valderrama, I. J. (2019). The EU Standard of Good Governance in Tax Matters for Third (Non-EU) Countries, Intertax, 47(5), 454-467.

News \& Speeches (2017) from the International Chamber of Commerce, ICC welcomes OECD's landmark global tax agreement.

Nicolescu, A.F., Drăgan, G. (2020). "Integrating the non-EU immigrants into the EU labour market. An econometric analysis of some of the specific factors", Management \& Marketing. Challenges for the Knowledge Society, 15(3), 364-380, DOI: 10.2478/mmcks2020-0021.

OECD (2021). Developing Countries and the OECD/G20 Inclusive Framework on BEPS.

Păunescu, C., Mátyus, E. (2020). "Resilience measures to dealing with the Covid-19 pandemic. Evidence from Romanian micro and small enterprises", Management \& Marketing. Challenges for the Knowledge Society, Vol. 15, No. Special Issue, 439-457, DOI: $10.2478 / \mathrm{mmcks}-2020-0026$.

Pirvu, D. (2012). Corporate Income Tax Harmonization in the European Union, Palgrave Macmillan Studies in Banking and Financial Institutions.

Press release (2008) from the Council on the $2911^{\text {th }}$ meeting of the Council of the European Union

Press release (2008) from the Council on the $2866^{\text {th }}$ Council Meeting of the Economic and Financial Affairs.

Press release (2020) from the Council, Taxation: Council revises its EU list of non-cooperative jurisdictions.

Recommendation (2012) from the Commission on aggressive tax planning.

Recommendation (2016) from the Commission on the implementation of measures against tax treaty abuse.

Report (1999) from the Code of Conduct Group (Business Taxation) to the ECOFIN Council on 29 November 1999, Code of Conduct (Business Taxation).

Report (2015) from the European Parliament on tax avoidance and tax evasion as challenges for governance, social protection and development in developing countries, Committee on Development.

Remeur, C. (2019). Understanding BEPS. From tax avoidance to digital tax challenges, European Parliamentary Research Service.

Staff Working Document (2015) from the European Commission. Collect more - spend better. Achieving Development in an Inclusive and Sustainable Way.

Viray, V.B. (2017). Base Erosion and Profit Shifting (BEPS) Inclusive Framework implementation in the Southeast Asian region, Financier Worldwide Magazine. 